\title{
A Comparative Study on Intranasal Versus Intravenous Lorazepam in the Management of Acute Seizure in Children
}

\author{
Nandan Rudra ${ }^{1}$, Taraknath Ghosh ${ }^{2}$, Uttam Kumar Roy ${ }^{3}$ \\ ${ }^{1}$ Kalna Subdivisional and Superspeciality Hospital, Purba Burdwan, West Bengal, India \\ ${ }^{2}$ Department of Paediatric Medicine, Burdwan Medical College and Hospital, Purba Burdwan, West Bengal, India \\ ${ }^{3}$ Department of Pharmacology, Raiganj Government Medical College and Hospital, Raiganj, Uttardinajpur, West Bengal, India
}

Corresponding author: Uttam Kumar Roy, Dilip Das Sarani, Hill View Main, Paschim Bardhaman, Pin-713304, West Bengal, India; E-mail: uroy951@gmail.com; Tel.: 9434163225

Received: 19 Nov 2020 Accepted: 8 Feb 2021 Published: 31 Dec 2021

Citation: Rudra N, Ghosh T, Roy UK. A comparative study on intranasal versus intravenous lorazepam in the management of acute seizure in children. Folia Med (Plovdiv) 2021;63(6):958-64. doi: 10.3897/folmed.63.e60938.

\begin{abstract}
Introduction: The acute seizure in childhood is a medical emergency which is usually managed by benzodiazepines used as a first line of therapy. There are no strict guidelines of using intranasal lorazepam in India. Many paediatricians use it in an emergency situation as it is inexpensive, easy to administer and even treatment can be started at home. Very few studies are available to compare efficacy and safety of intravenous lorazepam with intranasal lorazepam in childhood seizure, though both routes have comparable pharmacokinetic profile. Intravenous lorazepam $(0.1 \mathrm{mg} / \mathrm{kg})$ is already recommended as a first-line treatment of acute childhood seizures in India. There are very few studies regarding the usefulness of intranasal lorazepam. With this background, we compared intranasal lorazepam with the more widely accepted intravenous lorazepam for control of acute seizure.
\end{abstract}

Aim: To compare effectiveness and safety of intranasal and intravenous lorazepam in acute seizure in children aged 5-12 years.

Materials and methods: This is an analytical observational cross-sectional study involving patients with acute seizure who received lorazepam via either the intravenous or intranasal route. Formulation and dosage of lorazepam were the same in both routes.

Results: Distributions of patient groups according to sex, age, and weight were statistically not significant $(p=0.42, p=0.391$, and $p=0.605$, respectively). Time to control seizure within $10 \mathrm{~min}$ and persistent cessation of seizure activity were similar in both groups. Safety parameters showed no differences statistically.

Conclusions: Though intravenous lorazepam is recommended as first-line treatment, intranasal lorazepam may be a good alternative choice in a convulsing child.

\section{Keywords}

children, efficacy, intranasal, intravenous, lorazepam, seizure

\section{INTRODUCTION}

Acute seizures or convulsions are a common medical emergency in children worldwide with an overall annual incidence of 10-41 per $100000 .{ }^{1}$ Acute seizure can cause unre- lenting muscular activity leading to anaerobic metabolism and tissue breakdown as well as increase of the cerebral metabolic rate exceeding the oxygen and glucose supply to the brain leading to brain ischemia and neuronal death. ${ }^{2}$ Thus it is important to control seizures rapidly to minimize the systemic as well as brain damage.

Copyright by authors. This is an open access article distributed under the terms of the Creative Commons Attribution License (CC-BY 4.0), 
The goal of pharmacologic therapy is to achieve rapid and safe termination of the seizure and to prevent its recurrence, without adverse effects on the cardiovascular and respiratory systems. Drugs used to control status epilepticus are benzodiazepine (lorazepam/diazepam/midazolam), phenytoin/phosphenytoin, phenobarbitone, valproate, propofol, thiopental, etc. in a systemic sequence as per protocol. ${ }^{3}$ Intravenous or intramuscular routes are usually preferred in a hospital set-up whereas other routes like intranasal route can also be used in any situation even at home, school, road, etc. Benzodiazepines are effective first-line anticonvulsants for treatment of acute seizures. Diazepam is widely available and inexpensive. It can be given intravenous or per rectally. It acts rapidly but it is short acting, breakthrough seizures are common and can cause respiratory depression. ${ }^{4,5}$ Intranasal midazolam is widely available, but it is short acting ${ }^{6}$ and consequently associated with seizure recurrence. ${ }^{7}$

Lorazepam is inexpensive, long acting (up to $72 \mathrm{~h}$ ) 8 ,9 and has less risk of seizure recurrence ${ }^{10}$. Intravenous lorazepam $(0.1 \mathrm{mg} / \mathrm{kg})$ is recommended as a first-line treatment of acute childhood seizures. ${ }^{11}$ However, starting an IV can be difficult or time consuming in patients with convulsive limb activity. It would be advantageous to have a route of delivery that did not require personnel skilled at starting IV route.

Intranasal lorazepam may be an alternative route of administration of lorazepam as it is well absorbed from nasal mucosa, with rapid action and comparable elimination profiles to IM and IV routes. ${ }^{12}$ Intravenous lorazepam $(0.1 \mathrm{mg} / \mathrm{kg})$ is already recommended as a first-line treatment of acute childhood seizures, but there are very few studies regarding the usefulness of intranasal lorazepam in acute childhood seizure. Hence, in our present study we want to compare intranasal lorazepam with the more widely accepted standard intravenous lorazepam for control of acute seizure in children.

\section{AIM}

1. To compare effectiveness of intranasal lorazepam with intravenous lorazepam in management of acute seizure in children aged 5-12 years.

2. To compare adverse effects of intranasal lorazepam with intravenous lorazepam in the management of acute seizure in children aged 5-12 years.

\section{MATERIALS AND METHODS}

After the approval of the Institutional Ethics Committee of Burdwan Medical College and Hospital and permission of the West Bengal University of Health Sciences (WBUHS), the present thesis work was carried out in the Department of Paediatric Medicine, Burdwan Medical College and Hospital, Burdwan (West Bengal, India) from March 2016 to February 2017. This is an observational analytical cross-sectional study, with 80 participants in each group using purposive sampling technique. Children (5-12 years) with acute convulsion were included in our study. Those who received anticonvulsants within $1 \mathrm{hr}$ prior of admission, having any hypersensitivity to benzodiazepine, upper respiratory tract infection, nasal pathology, presence of cardiorespiratory compromise, cerebrospinal fluid rhinorrhea and whose guardians refused consent were excluded from the study. Efficacy parameters studied were cessation of all clinical seizure activity within $10 \mathrm{~min}$ of drug administration, persistent cessation of seizure activity for $1 \mathrm{hr}$ without requiring rescue medication, time to achieve intravenous access after arrival in a paediatric ward, time from drug administration to termination of seizure(s) and hospital stay in days. Other parameters assessed include efficacy comparison with respect to type of seizure and prior chronic AED (antiepileptic drug) use. Safety parameters included were development of hypotension (fall of $\geq 20 \mathrm{~mm} \mathrm{Hg}$ systolic and/or $\geq 10 \mathrm{~mm} \mathrm{Hg}$ diastolic pressure) within $1 \mathrm{hr}$ of drug administration, development of significant respiratory depression requiring assisted ventilation and comparison of mortality between groups. Study tools we used were written consent form, detailed data record proforma, oxygen source IV cannula, inj. lorazepam $(2 \mathrm{mg} / \mathrm{ml}$ and benzyl alcohol $2 \% \mathrm{v} / \mathrm{v}$ ), suction catheter, pulse oxymeter, and a blood pressure monitor.

After initial stabilization of the airway, breathing, and circulation, a brief history was taken and clinical examination was carried out. Then after taking written informed consent from the parents/guardian and taking samples for relevant investigations, the patients with active convulsion (meeting the above inclusion and exclusion criteria) received lorazepam either via the intravenous (IV) or the intranasal (IN) route as per decision of paediatrician though there are no clear cut guidelines of using an IN route.

In INLOR group patients received IN lorazepam directly instilled into any one nostril, with the patient in a supine position, drop by drop over 30-60 s. The formulation and dosage of IN lorazepam were same as the IV formulation containing lorazepam British Pharmacopeia (BP) $2 \mathrm{mg} / \mathrm{ml}$ and benzyl alcohol $2 \% \mathrm{v} / \mathrm{v}$ at the dose of $0.1 \mathrm{mg} / \mathrm{kg}(0.05$ $\mathrm{ml} / \mathrm{kg}$ ) to a maximum of $4 \mathrm{mg}$. Other group of patients (IVLOR) received lorazepam in IV. The time interval from administration of lorazepam to cessation of seizures was recorded. In both groups, vital measurements like $H R, R R$, $\mathrm{BP}$, and $\mathrm{SpO}_{2}$ were noted every $5 \mathrm{~min}$ for the first $20 \mathrm{~min}$, and then every $10 \mathrm{~min}$ for a total of 60 minutes. The time of drug administration was taken as $0 \mathrm{~min}$ and all measurements were made with that reference.

Patients were assessed for persistence of clinically visible motor seizure activity at the end of $10 \mathrm{~min}$. If seizures persisted or recurred after an initial period of remission, IV phenytoin was given at a dose of $20 \mathrm{mg} / \mathrm{kg}$ diluted in normal saline at a rate not exceeding $1 \mathrm{mg} / \mathrm{kg} / \mathrm{min}$. If no seizure persisted or recurred, this was taken as a positive primary outcome and patients were observed for $1 \mathrm{~h}$ and then maintenance AEDs were given and managed as usual.

All the data were recorded in a predesigned proforma. 
The efficacy of intravenous lorazepam was compared with intranasal lorazepam in other group and the response was compared between the two groups in terms of significance using Mann Whitney test or Student t-test (for quantitative data) and Fisher's exact tests or Chi-square test (for qualitative data) whichever applicable. $P$ value of $<0.05$ were taken as statistically significant for analysis. SPSS Version 17 was used for the purpose of analysis.

\section{RESULTS}

Most of the patients in both groups were boys. In the IN group, $60 \%$ of the patients were boys and in the IV group $53.8 \%$ were boys $(p>0.05)$. The mean age of the IN group of patients was 8.2 years and mean weight was $24.06 \mathrm{~kg}$ whereas in IV group the mean age and mean weight were 8.48 years and $24.51 \mathrm{~kg}$, respectively. Differences of age and weight between these two groups were not statistically significant $(p>0.05)$. The most common cause of seizure was CNS infections in our study (Table 1). In the IN group of patients $15 \%$ of the patients had a history of epilepsy and in the IV group of patients $20 \%$ of the patients had a history of epilepsy but the difference between the groups did not reach statistical significance $(p=0.405)$. Prior chronic AED use was $15 \%$ and $20 \%$, but the difference between both groups was statistically not significant $(p=0.405)$. History of current seizure duration in two groups was not different $(p=0.257)$. In the IN group, $81.25 \%$ of the patients had generalized tonic clonic seizure (GTCS) and in the IV group, $83.75 \%$ of the patients had GTCS, but the difference between the groups failed to reach statistical significance $(p=0.677)$. It was found that 15 and 13 patients had partial seizures in the INLOR and IVLOR groups, respectively. Eighty percent of the patients with partial seizures had seizure remission within $10 \mathrm{~min}$ of drug administration in the INLOR group and $92.3 \%$ of the patients had seizure remission within $10 \mathrm{~min}$ of drug administration in the IVLOR group. The differences between these two groups were statistically not significant $(p=0.353)$. The clinical scenario, including the history and physical examination, is the most important factor guiding the specific evaluation that each child will require. ${ }^{13}$ The investigations usually considered include blood chemistry, complete blood count, antiepileptic drug (AED) levels, toxicological studies, lumbar puncture, electroencephalography, and neuro-imaging (CT scan and MRI). The major part of evaluation can be performed after the child has been stabilized in an intensive care setting, and the seizures have been completely or partially controlled. ${ }^{13,14}$ Abnormal biochemical parameter in childhood seizure has been reported in many studies. We also performed tests to measure their levels such as serum electrolytes, complete haemogram, and blood glucose. ${ }^{13,15-17}$ The mean $\mathrm{Hb}$ values of the IN and IV groups were $10.75 \mathrm{gm} / \mathrm{dl}$ and $10.91 \mathrm{gm} / \mathrm{dl}$, respectively, total leucocyte count of these groups were $11432.5 / \mathrm{cmm}$ and $12041.25 /$ $\mathrm{cmm}$, respectively. The differences between these parameters in the two groups were not statistically significant $(p=0.08)$. Mean CRP of the IN and IV groups were $9.4 \mathrm{mg} / \mathrm{L}$ and $10.48 \mathrm{mg} / \mathrm{L}$, respectively. The difference between this parameter in the two groups did not reach statistical significance $(p=0.12)$. The biological parameters (blood glucose, serum Na, serum $\mathrm{Ca}$ ) between IN and IV groups were not statistically significant ( $p>0.05$ ). In $47.5 \%$ of the IN patients and in $56.25 \%$ of IV patients, abnormal CSF was found. The differences in both groups were statistically not significant $(p=0.268)$. CT scan of brain was done to detect the presence of any inflammatory granulomas and neuronal lesions if any. In the IN group, $22.22 \%$ of the patients and in the IV group, $14.64 \%$ of the patients had abnormal CT scan findings. The differences between these two groups were statistically not significant ( $p=0.389$ ). In the IN group, $56.45 \%$ of the patients had abnormal MRI findings. Abnormal MRI findings were observed in $48.39 \%$ of the patients in the IV group. The differences between these two groups were not statistically significant $(p=0.368)$. In the IN group, $55.56 \%$ of the patients had abnormal EEG findings and so were $63.89 \%$ of the patients in the IV group. So the differences between these two groups did not reach statistical significance ( $p=0.470$ ) (Table 2). Results of efficacy (seizure control within $10 \mathrm{~min}$, persistent cessation of seizure activity for $1 \mathrm{hr}$, mean time to control seizure and stay in hospital in days) and the safety parameters (mortality comparison, respiratory depression) are presented in Tables 3, 4 .

\section{DISCUSSION}

Children aged 5-12 years were included in our study presenting with active convulsion meeting the inclusion and exclusion criteria. Detailed recording of baseline clinical data with treatment outcome, detailed clinical examination and laboratory investigations were done for every patient. In our study, the mean age of the patients in the IN

Table 1. Distribution of patients with causes of active convulsion

\begin{tabular}{lllllll}
\hline Group & AED withdrawal & Seizure disorder & CNS infection & $\begin{array}{l}\text { Cerebrovascular } \\
\text { accident }\end{array}$ & Metabolic causes & $\begin{array}{l}\text { Inflammatory } \\
\text { granuloma }\end{array}$ \\
\hline INLOR & $5(6.2 \%)$ & $15(18.7 \%)$ & $38(47.5 \%)$ & $9(11.25 \%)$ & $3(3.75 \%)$ & $10(12.5 \%)$ \\
IVLOR & $3(3.7 \%)$ & $20(25 \%)$ & $45(56.2 \%)$ & $5(6.25 \%)$ & $2(2.5 \%)$ & $5(6.25 \%)$ \\
$p$ & 0.468 & 0.268 & 1.00 & 0.263 & 0.649 & 0.175 \\
\hline Total & 8 & 35 & 83 & 14 & 5 & 15 \\
\hline
\end{tabular}


Table 2. Results of efficacy

\begin{tabular}{llll}
\hline Efficacy parameter & INLOR $(\mathbf{n = 8 0})$ & IVLOR $(\mathbf{n = 8 0})$ & $\boldsymbol{p}$ \\
\hline Seizure remission within 10 min & $60(75 \%)$ & $66(82.5 \%)$ & 0.246 \\
Seizure cessation for $1 \mathrm{hr}$ & $50(62.5 \%)$ & $58(72.5 \%)$ & 0.177 \\
Time to seizure control (min) (mean \pm SD) & $6.26 \pm 5.28$ & $6.05 \pm 5.91$ & 0.798 \\
Hospital stay (days) (mean \pm SD) & $10.04 \pm 5.48$ & $10.48 \pm 4.69$ & 0.586 \\
\hline
\end{tabular}

Table 3. Results of safety

\begin{tabular}{llll}
\hline Safety parameter & INLOR $(\mathbf{n}=\mathbf{8 0})$ & IVLOR $(\mathbf{n}=\mathbf{8 0})$ & $\boldsymbol{p}$ \\
\hline Mortality & $5(6.25 \%)$ & $4(5 \%)$ & 0.732 \\
Respiratory depression & $1(1.25 \%)$ & $2(2.5 \%)$ & 0.560 \\
\hline
\end{tabular}

Table 4. Neurological findings

\begin{tabular}{llll}
\hline Neurological study & INLOR $(\mathbf{n}=\mathbf{8 0})$ & IVLOR $(\mathbf{n}=\mathbf{8 0})$ & $\boldsymbol{p}$ \\
\hline Abnormal EEG & $20(55.56 \%)$ & $23(63.89 \%)$ & 0.470 \\
Abnormal CT & $8(22.22 \%)$ & $6(14.64 \%)$ & 0.389 \\
Abnormal MRI & $35(56.45 \%)$ & $30(48.39 \%)$ & 0.368 \\
\hline
\end{tabular}

and IV groups was 8.2 and 8.48 years, respectively. Arya et al. report a mean age of 8.97 and 8.63 years in the IN and IV groups, respectively. ${ }^{18}$ In our study, most of the patients were male in both groups which was very similar to that study also, where most of the patients were male in both arms $(57.75 \%$ in the IN group and $51.43 \%$ in the IV group). ${ }^{18}$ This study included 71 children aged 6 years to 14 years in the INLOR arm of the study. The presenting seizure stopped within 10 min of INLOR administration in $83.10 \%$ of their patients, which is comparable to our figure.

The mean weights in our study were $24.06 \mathrm{~kg}$ and $24.51 \mathrm{~kg}$ in the IN and IV groups, respectively. In Lissauer et al. ${ }^{19}$, the mean weights were $10 \mathrm{~kg}$ and $10.4 \mathrm{~kg}$ in the IN and IV groups, respectively. ${ }^{19}$ The studied children aged 2 months to 14 years had shown that intranasal lorazepam was less effective than the IV lorazepam as a first-line treatment for acute seizures but may be useful in children without or with difficult IV access. ${ }^{19}$

In our study, with respect to seizure control, INLOR is not inferior to the current standard of practice IVLOR. The INLOR arm of the study by Ahmad et al. included 80 children aged 2 months to 12 years. ${ }^{20}$ The presenting seizure stopped within 10 min of INLOR administration in $75 \%$ of their patients, which is consistent with our results. LOR in childhood SE is most efficacious in the 5-11-year age group, with $92 \%$ having successful seizure control. ${ }^{21}$ In Ahmad et al. ${ }^{20}$, the efficacy of LOR is relatively modest (72-76\%) successful seizure control. ${ }^{31}$ This study used the time of drug administration as reference time or $0 \mathrm{~min}$.

In the present study, continued clinical seizure cessation for $1 \mathrm{~h}$ was observed, and it is obvious that INLOR is not inferior to IVLOR regarding duration of action. Prolonged duration of action for IVLOR is well established ${ }^{22}$; however, there is some evidence for similar long duration of action of INLOR also. In a pharmacokinetic study of healthy adult volunteers, INLOR showed a second delayed peak attributed putatively to inadvertent oral absorption, which likely contributed to prolonged efficacy. ${ }^{23}$ In the experience of Ahmad et al. ${ }^{20}$, only $10 \%$ of the patients in the INLOR arm $(\mathrm{N}=80)$ failed to achieve seizure remission within 1 hour. An Indian study by Arya et al. ${ }^{18}$ also showed clinical seizure cessation for $1 \mathrm{~h}$ was in $62.5 \%$ in the IN $\operatorname{arm}(\mathrm{N}=71)$ which is very close to our study of $62 \%$.

In this study, the average (mean) time to achieve seizure showed no significant difference between two arms. Arya et al. ${ }^{18}$ found a median time for seizure cessation of $3 \mathrm{~min}$ in both arms which is comparable to our data. Ahmad et $\mathrm{al}^{20}$ found a median time for seizure cessation of $7.5 \mathrm{~min}$, inter-quartile range (IQR) $4.5-11.5 \mathrm{~min}$. This is difficult to explain, but probably results from differences in age and etiologic profile of our patients and lack of use of the atomizer device by us. However, our experience agrees with the data from healthy adults for which peak bioavailability was achieved within 5 min. ${ }^{23}$

Time to achieve intravenous access after arrival in the paediatric ward took a median of $6 \mathrm{~min}$ (range 2-25 min) to achieve peripheral venous access. This shows that even in a well-equipped, tertiary-level ER with skilled residents, valuable time of up to 25 min may be lost in struggling for peripheral venous access in a convulsing child. Intranasal administration, however, is virtually instantaneous and does not require any special skills. Arya et al. found a median of 4 min (range 1-25 min) to achieve peripheral venous access. ${ }^{18}$

There is a justifiable concern that prior AED use might 
influence the efficacy of benzodiazepines for seizure control. In patients on prior AEDs, study finding supports pharmacokinetic data showing comparable bioavailability with IV and IN administration of LOR. ${ }^{23}$ This finding is also supported by Arya et al. ${ }^{18}$ A more relevant question is whether the efficacy of INLOR differs in patients on or not on chronic AEDs. Seizure cessation with INLOR was observed in $75 \%$ of patients on AED as compared to $75 \%$ of those not on them. Although sufficient power is lacking to draw valid conclusions, these suggest that INLOR may be an acceptable alternative to IVLOR in these patients.

INLOR achieved seizure control within $10 \mathrm{~min}$ of administration in $73.85 \%$ of patients with generalized and $80 \%$ of those with partial seizures. Continued seizure cessation for $1 \mathrm{hr}$ was seen in $58.5 \%$ of patients with generalized and $80 \%$ of those with partial seizures, who received INLOR. Arya et al. ${ }^{18}$ also showed that INLOR achieved seizure control within 10 min of administration in $78 \%$ of patients with generalized and $82 \%$ of those with partial seizures. Continued seizure cessation for $1 \mathrm{~h}$ was seen in $57 \%$ of patients with generalized and $66 \%$ of those with partial seizures, who received INLOR. These data are comparable to our study that support to the hypothesis that INLOR may be an acceptable alternative to IVLOR for different seizure types.

While considering safety of lorazepam, no patients in the present study developed hypotension (fall of $\geq 20$ $\mathrm{mmHg}$ systolic and/or $\geq 10 \mathrm{mmHg}$ diastolic pressure) within $1 \mathrm{~h}$ of drug administration. Ahmad et al. ${ }^{20}$ found a median decrease in systolic pressure of $7 \mathrm{~mm} \mathrm{Hg}$ and diastolic pressure of $7.5 \mathrm{~mm} \mathrm{Hg}$, with no requirement for intervention. Arya et al. ${ }^{18}$ did not find any significant hypotension within $1 \mathrm{hr}$ of drug administration. One patient in the present study from the IN arm required intubation and assisted ventilation. This patient had convulsive SE of $>30 \mathrm{~min}$ prior to reporting to the ER and was hypoxic and had suboptimal respiratory status at presentation. Therefore, it is difficult to attribute respiratory compromise entirely to INLOR administration. In the IV arm, two patients required assisted ventilation. Arya et al. ${ }^{18}$ showed similar results. Ahmad et al. ${ }^{20}$ compared intranasal lorazepam with intramuscular paraldehyde on 160 children aged 2 months to 12 years with seizures persisting for more than $5 \mathrm{~min}$ and found better results with intranasal lorazepam. No clinically significant cardiorespiratory events were seen in either group. Arya et al. ${ }^{18}$ compared intranasal lorazepam with intravenous lorazepam on 141 children aged 6 years to 14 years presented convulsing and concluded IN lorazepam is not inferior to IV lorazepam. This study evaluates seizure cessation within $10 \mathrm{~min}$ in $80 \%$ of the intravenous group compared to $83.1 \%$ of the intranasal group and none in either group developed significant adverse effects.

According to Lissauer et al. ${ }^{19}$ also, there were no significant cardio-respiratory events and no difference in mortality or neurological deficits. Wermeling DP et al. has shown intranasal lorazepam to be a suitable alternative if recurrence of seizures is a potential concern..$^{24}$ Because our sample size was insufficient to capture enough adverse effects, this study was underpowered to conclude meaningfully with respect to the difference in the incidence of adverse effects between the groups.

Limitations of our study include small sample size, and lack of atomizer device for instillation of INLOR. One important aspect of management is facility of video EEG monitoring which is lacking in our setup. An electroencephalogram (EEG) to look for abnormal patterns of brain waves and neuroimaging (CT scan or MRI) to look at the structure of the brain are also usually part of the workup. ${ }^{25}$ While figuring out a specific epileptic syndrome is often attempted, it is not always possible. ${ }^{25}$ Video and EEG monitoring may be useful in difficult cases. ${ }^{26}$ No Indian studies on usefulness of EEG in pediatric status epilepticus are available. EEG abnormalities have been reported in $90 \%$ of children presenting with status epilepticus, though these were done hours to days later. ${ }^{27}$ After a convulsive episode is over, some cases experience entirely electrographic only seizures. ${ }^{28,29}$

Neuroimaging can identify structural causes for seizure, especially to exclude the need for neurosurgical intervention in children with new onset seizures without a prior history of epilepsy, or in those with persistent seizure despite appropriate treatment. MRI is more sensitive and specific than CT scanning, but CT is more widely available and quicker in an emergency setting. In a more recent study ${ }^{30}$, the yield of MRI to detect structural lesions in acute convulsion was $31 \%$. In the Indian setting, where inflammatory granulomas are a common cause of seizures $^{31}$, neuroimaging is likely to provide a higher yield.

\section{CONCLUSIONS}

Acute seizure in children requires proper and prompt treatment to prevent morbidity and mortality. Early seizure control prevents neurological sequelae and improves outcomes. Intravenous lorazepam $(0.1 \mathrm{mg} / \mathrm{kg})$ is recommended as a firstline treatment of acute childhood seizures. However, starting an IV can be difficult or time consuming in patients with convulsive limb activity. The risk of accidental needle stick injury to health care personnel also increases when patients have active convulsions. In many emergency settings, such as in patients with known refractory seizures, or in mass causality environments, it would be advantageous to have a route of delivery that did not require personnel skilled at starting an IV. Intranasal lorazepam is well absorbed from nasal mucosa, with rapid action and comparable elimination profiles to IM and IV routes. Thus, intranasal lorazepam may be a good alternative choice in a convulsing child even before reaching the hospital or in cases of IV access failure in a hospital.

We can conclude from the study that INLOR $(0.1 \mathrm{mg} /$ $\mathrm{kg}$, maximum $4 \mathrm{mg}$ ) is not inferior to IVLOR as first-line treatment for acute seizures in children aged 5-12 years and can be useful for the termination of acute seizures in any circumstances or in children with difficult IV access. Even intranasal route is not inferior to intravenous route for con- 
tinued seizure remission for 1 hour and is also comparable with respect to median time from drug administration to termination of seizure. There are no clinically significant cardiorespiratory adverse events of INLOR or IVLOR in the management of acute seizures in children. It is obvious from the literature survey that in the last few years, there have been no studies reporting the role and comparing the intranasal lorazepam with intravenous lorazepam in an acute seizure in children. Our study in this respect will obviously help in decision making process. Authors suggest carrying out a trial involving large number of participants and EEG monitoring of the events as some cases experience entirely electrographic-only seizures.

\section{Competing interests}

The authors have declared that no competing interests exist.

\section{Funding}

The authors have no funding to report.

\section{Acknowledgements}

The authors have no support to report.

\section{REFERENCES}

1. Mikati MA, Hani AJ. Seizures in childhood. In: Kliegman RM, Stanton BF, Geme St JW, Schor NF, editors. Nelson Textbook of Pediatrics $2015 ; 20: 2823-57$

2. Choi J, Nordli DR, Alden TD, et al. Cellular injury and neuroinflammation in children with chronic intractable epilepsy. J Neuroinflammation 2009; 6(1):1-4.

3. Rajyadhyaksha S, Kalra V, Potharaju NR, et al. Guidelines for diagnosis and management of childhood epilepsy. Expert Committee on Pediatric Epilepsy, Indian Academy of Pediatrics. Indian Pediatr 2009; 46:681-98.

4. Leppik LE, Derivan AT, Homan RW, et al. Double-blind study of lorazepam and diazepam in status epilepticus. JAMA 1983; 249(11):1452-4.

5. Ogutu BR, Newton CR, Crawley J, et al. Pharmacokinetics and anticonvulsant effects of diazepam in children with severe falciparum malaria and convulsions. Br J Clin Pharmacol 2002; 53(1):49-57.

6. Riss J, Cloyd J, Gates J, et al. Benzodiazepines in epilepsy: pharmacology and pharmacokinetics. Acta Neurol Scand 2008; 118(2):69-86.

7. Hayashi K, Osawa M, Aihara M, et al. Efficacy of intravenous midazolam for status epilepticus in childhood. Pediatr Neurol 2007; 36(6):366-72.

8. Joint Formulary Committee. British National Formulary. London: BMJ Group and Pharmaceutical Press; 2012.

9. Rey E, Tréluyer JM, Pons G. Pharmacokinetic optimisation of ben- zodiazepine therapy for acute seizures. Clin Pharmacokinet 1999; 36(6):409-24.

10. Cock HR, Schapira AH. A comparison of lorazepam and diazepam as initial therapy in convulsive status epilepticus. Qjm 2002; 95(4):225-31.

11. Appleton R, Choonara I, Martland T, et al. The treatment of convulsive status epilepticus in children. The Status Epilepticus Working Party, Members of the Status Epilepticus Working Party. Arch Dis Child 2000; 83:415-9.

12. Wermeling DP, Miller JL, Archer SM, et al. Bioavailability and pharmacokinetics of lorazepam after intranasal, intravenous, and intramuscular administration. J Clin Pharmacol 2001; 41(11): 1225-31.

13. Mastrangelo M, Celato A. Diagnostic work-up and therapeutic options in management of pediatric status epilepticus. World J Pediatr 2012; 8(2):109-15.

14. Mehrotra P, Marwaha RK, Aneja S, et al. Hypovitaminosis D and hypocalcemic seizures in infancy. Indian Pediatr 2010; 47:581-6.

15. Balasubramanian S, Shivbalan S, Kumar PS. Hypocalcaemia due to vitamin D deficiency in exclusively breastfed infants. Indian Pediatr 2006; 43:247-51.

16. Shorvon S, Ferlisi M. The treatment of super-refractory status epilepticus: a critical review of available therapies and a clinical treatment protocol. Brain 2011; 134(Pt 10):2802-18.

17. Wijdicks EFM. The multifaceted care of status epilepticus. Epilepsia 2013; 54:61-3.

18. Arya R, Gulati S, Kabra M, et al. Intranasal versus intravenous lorazepam for control of acute seizures in children: a randomized openlabel study. Epilepsia 2011; 52(4):788-93.

19. Lissauer S, Kenny J, Jefferis O, et al. [Buccal, intranasal or intravenous lorazepam for the treatment of acute convulsions in children in Malawi: An open randomized trial] Afr J Emerg Med 2015; 5(3):120-6 [Article in French].

20. Ahmad S, Ellis JC, Kamwendo H, et al. Efficacy and safety of intranasal lorazepam versus intramuscular paraldehyde for protracted convulsions in children: an open randomised trial. Lancet (London, England) (2006); 367(9522):1591-7.

21. Crawford TO, Mitchell WG, Snodgrass SR. Lorazepam in childhood status epilepticus and serial seizures: effectiveness and tachyphylaxis. Neurology 1987; 37:190-5.

22. Schmidt D. Benzodiazepines: clinical efficacy and use in epilepsy. In: Levy RH, Meldrum BS, Mattson RH, Perucca E, editors. Antiepileptic drugs. Philadelphia: Lippincott, Williams \& Wilkins; pp. 206-14.

23. Wermeling DP, Miller JL, Archer SM, et al. Bioavailability and pharmacokinetics of lorazepam after intranasal, intravenous, and intramuscular administration. J Clin Pharmacol 2001; 41:1225-31.

24. Wermeling DP. Intranasal delivery of antiepileptic medications for treatment of seizures. Neurotherapeutics 2009; 6(2):352-8.

25. Gilad R, Izkovitz N, Dabby R, et al. Treatment of status epilepticus and acute repetitive seizures with IV Valproic acid vs. phenytoin. Acta Neurol Scand 2008; 118:296-300.

26. Shorvon S, Ferlisi M. The treatment of super-refractory status epilepticus: a critical review of available therapies and a clinical treatment protocol. Brain 2011; 134(Pt 10):2802-18.

27. Maytal J, Novak G, Ascher C, et al. Status epilepticus in children with epilepsy: the role of antiepileptic drug levels in prevention. Pediatrics 1996; 98:1119-21.

28. Sánchez FI, Abend NS, Arndt DH, et al. Electrographic seizures after convulsive status epilepticus in children and young adults: a retro- 
spective multicenter study. J Pediatr 2014; 164(2):339.

29. Yoong M, Madari R, Martinos M, et al. The role of magnetic resonance imaging in the follow-up of children with convulsive status epilepticus. Dev Med Child Neurol 2012; 54(4):328-33.

30. Singhi P. Neurocysticercosis. Ther Adv Neurol Disord 2011; 4(2):67-81.

31. Eriksson KJ, Koivikko MJ. Status epilepticus in children: Etiology, treatment, and outcome. Dev Med Child Neurol 1997; 39:652-8.

\title{
Сравнительное исследование интраназального и внутривенного лоразепама в лечении острых припадков у детей
}

\author{
Нандан Рудра ${ }^{1}$, Таракнат Гош ${ }^{2}$, Утам Кумар Рой $^{3}$ \\ ${ }^{1}$ Районная специализированная больница Калны, Пурба Бурдван, Западная Бенгалия, Индия \\ ${ }^{2}$ Отделение педиатрической медищины, Медицинский колледж и больница Бурдвана, Пурба Бурдван, Западная Бенгалия, Индия \\ ${ }^{3}$ Кафедра фармакологии, Государственный медииинский колледж и больница Райганджа, Райгандж, Утардинаджпур, Западная Бенгалия, \\ Индия
}

Адрес для корреспонденции: Утам Кумар Рой, Дилип Дас Сарани, Хил Вю Мейн, Пасхим Бардхаман, Пин - 713304, Западная Бенгалия, Индия; E-mail: uroy951@gmail.com; Тел.: 9434163225

Дата получения: 19 ноября $2020 \bullet$ Дата приемки: 8 февраля $2021 \bullet$ Дата публикации: 31 декабря 2021

Образец цитирования: Rudra N, Ghosh T, Roy UK. A comparative study on intranasal versus intravenous lorazepam in the management of acute seizure in children. Folia Med (Plovdiv) 2021;63(6):958-64. doi: 10.3897/folmed.63.e60938.

\section{Резюме}

Введение: Острые судороги у детей - это неотложное заболевание, которое обычно лечится с помощью бензодиазепинов, используемых в качестве лечения первого выбора. В Индии нет строгих рекомендаций по применению лоразепама для интраназального введения. Многие педиатры используют его в экстренных случаях, потому что он недорогой, простой в применении и даже лечение можно начать дома. Существует несколько исследований, сравнивающих эффективность и безопасность лоразепама для внутривенного введения и лоразепама для интраназального введения при припадках у детей, хотя оба пути введения имеют сопоставимый фармакокинетический профиль. Внутривенный лоразепам (0.1 мг / кг) уже рекомендован для лечения первой линии острых припадков у детей в Индии. Есть несколько исследований о пользе лоразепама для интраназального введения. Исходя из этого, мы сравнили лоразепам для интраназального введения с более широко применяемым лоразепамом для внутривенного введения для контроля острых приступов.

Цель: Сравнить эффективность и безопасность интраназального и внутривенного лоразепама при острых судорогах.

Материалы и методы: Это аналитическое исследование текущего состояния путём наблюдения, включая пациентов с острыми припадками, принимающих лоразепам внутривенно или интраназально. Формула и дозировка лоразепама были одинаковыми для обоих способов введения.

Результаты: Распределение групп пациентов по полу, возрасту и весу не было статистически значимым ( $p=0.42, p=0.391$ и $p=0.605$ соответственно). Время для контроля приступов в течение 10 минут и стойкое прекращение судорожной активности были одинаковыми в обеих группах. Параметры безопасности не показали статистической разницы.

Заключение: Хотя внутривенный лоразепам рекомендуется в качестве лечения первого выбора, интраназальный лоразепам может быть хорошей альтернативой для ребёнка с судорогами.

\section{Ключевые слова}

дети, эффективность, интраназальный, внутривенный, лоразепам, судороги 